Borneo Journal of Science \& Technology, Volume (2), Issue (2), Pages: 59-71

DOI: http://doi.org/10.3570/bjost.2020.2.2-10

e-ISSN: 2672-7439

(C) 2018, UCTS Publisher.

Submitted: $27^{\text {th }}$ May 2020

Accepted: $10^{\text {th }}$ June 2020

Published: $31^{\text {th }}$ July 2020

\title{
Spatial Variation in the Abundances of Threatened Resident Avifauna across Sabah: A Meta-Analysis
}

\author{
*Wing Shen Lim and Andy Russel Mojiol
}

Faculty of Science and Natural Resource, Universiti Malaysia Sabah (UMS), Malaysia.

\begin{abstract}
Threatened resident bird species are dependent on local habitats for survival, and then habitat degradation can lead to the extinction of these avian species in Sabah. Henceforth, this paper intends to utilise meta-analysis in examining the spatial variation in abundances of these species, plus the influences of habitat conditions towards this matter across Sabah. A total of 16 past articles that reported the count data on threatened resident species in Sabah were selected, where 21 species and 475 individuals were included in the meta-analysis. The findings of this paper indicated that only certain species and groups of species showed spatial variation in abundances between different managements, forest types and forest conditions, such as Chestnut-necklaced Partridge (Arborophila charltonii) that was significantly more abundant at commercial forest reserves, while the Hook-billed Bulbul (Setornis criniger) was significantly more abundant at state lands, compared to other habitats with different management. Then, Rhinoceros Hornbill (Buceros rhinoceros) was significantly more abundant at the mixed lowland dipterocarp forests compared to other forest types in Sabah. This research excludes the assessment onto the interrelated influence of these three parameters, and also the effects of elevation and other forest types towards spatial variation in abundances of these species across different habitats. Therefore, further research is required to fill-up these research gaps and provide a much holistic understanding on the effect of habitat conditions towards spatial variation in abundances of threatened resident bird species across Sabah in future.
\end{abstract}

Keywords: Habitat Preference, Resident Bird, Sabah, Spatial Distribution, Threatened Species

\section{INTRODUCTION}

A total of 669 species of avifauna have been discovered in the Borneo. The majority of them can be observed in the state of Sabah, which is in the Northern region of Borneo [34]. A wide range of migratory and resident bird species can be observed throughout Sabah [16];[28];[31]. But then, more than half of these species depend on natural forests for survival, and then only about $55.0 \%$ of them can adapt and survive at the human-modified habitats [7]. This is because the habitat degradation can reduce the local availabilities of shelter and food, hence can limit the local population size and species diversity of the bird community that inhabits this habitat at a time [27];[31]. Due to that, certain species and individuals of avifauna may migrate to other habitats temporarily or permanently, leaving mostly the resident disturbance-tolerant and habitatspecialist bird species behind at the given habitat in small population sizes [4]. Besides that, the impact of habitat degradation is severer towards the resident habitat-specialist species than to the migratory and resident disturbance-tolerant species, because foods and shelters for the habitat-specialist species are limited only at the interior segment of disturbed habitat. On the contrary, foods and shelters that are favourable for the migratory and resident disturbance-tolerant species can be found at both the interior and exterior regions of this habitat [27];[31]. Henceforth, resident habitat-specialist species are more likely to face the risk of extinction that was caused by habitat degradation, when compared to the resident disturbance-tolerant and migratory species presented at a particular habitat in Sabah.

Recently, the International Union of Conservation for Nature and Natural Resources (IUCN) revealed that approximately $9.42 \%$ or 63 avian species in Malaysia were classified as "Threatened Species" [21]. Then, the habitat preference of these species at a particular region or biome was frequently examined by past researchers [16];[25];[28];[31];[45]. Nonetheless, similar studies are yet to be conducted for the threatened resident species that highly depend on various habitats presented across Sabah for survival at this moment. Because of that, the spatial variation in abundance of a threatened resident species across Sabah remains a mystery to be solved by researchers in future, and then meta-analysis

Corresponding Author: Wing Shen Lim. Faculty of Science and Natural Resource, Universiti Malaysia Sabah (UMS),

E-mail: limwingshen@gmail.com. 


\section{Spatial Variation in the Abundances of Threatened Resident Avifauna across Sabah: A Meta-Analysis}

is verified as a suitable approach for conducting this type of study by past researchers [5];[12];[17];[26].

Ferrer [15] reported that the meta-analysis allowed researchers to combine numerous relevant past findings and obtain a new estimate of an assessment with higher precision and accuracy. In most cases, a wildlife-related past study that involved field data collection could only cover limited study sites at a time. Therefore, there is an increasing trend in utilising the meta-analysis approach to cover a wider spatial scale in wildlife-related studies [5];[12];[17];[26]. The assessment of spatial variation in abundance of various threatened resident bird species across different habitats of Sabah through field survey are both time and resource-consuming, therefore metaanalysis functions as a better approach for this type of research. Likewise, some of the threatened resident bird species are elusive, and then the information on to their respective preferred habitats remain scarce as well at this moment [25]. Therefore, it is vital to determine the habitats with a higher probability of observing a certain threatened resident species beforehand, so that detailed field research can be conducted on the given species at the selected habitats in the future.

Long story short, this study intends to apply metaanalysis in examining the spatial variation in abundance of different threatened resident avifauna species across Sabah. The high abundance of a bird species at a certain habitat indicates that this habitat is highly occupied by this particular species [37], thus suitable for conducting further research onto the given species at this habitat in the future. Furthermore, factors with influences towards the difference in abundance of threatened resident bird species across different habitats are investigated in this study. The existing condition of a habitat determines its capability to provide the foods and shelters to support the livelihoods of many different wildlife species and individuals at a time [47]. In sum, high abundance and diversity of avifauna are presented at a least-disturbed habitat, because this habitat has the capability to supply higher variation and abundance of foods and shelters to support the lives of the local avifauna community, and vice versa for the disturbed habitat [12];[17]. However, different species of avian exhibit different species traits, which can create a difference in the adaptive responses exhibited by the respective bird species towards habitat degradation at a particular habitat [17];[45]. Due to that, the relationship between habitat conditions and species traits in affecting the abundance of a threatened resident bird species at a certain habitat will be further discussed in this research.

\section{RESEARCH METHODOLOGY}

\section{Database Construction}

A total of 16 past research studies that provided count data on the number of sighting for an avian species that was found in Sabah were selected as research materials. Two search engines, which were "Google Scholar" and "ScienceDirect.com", were employed in locating these past studies, based on the keywords liked "Threatened", "Resident", "Sabah", "Avifauna", "Avian", and "Bird". Information regarding the habitat condition and local avifauna community were extracted and then computed to construct a database for this research. By referring to this database, a total of 14 study sites and 19 sampling areas were examined in the given past studies and then threatened resident bird species were reported sighted at the given areas. Table 1 shows the general descriptions of the 14 study sites and 19 sampling areas included in the quantitative meta-analysis of this study.

\section{Data Analysis}

Seven IUCN Red List Status was assigned to represent the existing population size and risk of extinction faced by wildlife species in the wild. A wildlife species with large and stable population size is classified as "Least Concern" (LC), and then the shrinking in its population size and stability will result in changing its status into "Near-threatened" (NT), and followed by "Vulnerable" (VU), "Endangered" (EN), and "Critically Endangered" (CR), until it becomes "Extinct in the Wild" (EX), and ultimately "Extinct" (EX) from the world. Furthermore, wildlife species that are unable to repopulate faster than the decreasing in their population sizes are declared as "Threatened species" (VU, EN and CR). Therefore, any bird species that were not assigned with the IUCN Red List Statuses of VU, EN or CR, as well as those which were determined as full migrant species, were excluded from this study. In the end, only 21 out of 355 species $(5.92 \%)$ and 475 out of 13,564 individuals $(3.50 \%)$ of avian that were reported in the given past studies were included in the quantitative meta-analysis of this study.

Next, Lambert [25] and Rotenburg [37] classified habitat preferences of avifauna into six different groups, which were 1) Edge specialists (ES); 2) Edge tolerant forest specialists (ETF); 3) Generalist (G); 4) Forest specialists (FS); 5) Open Country Species (OS), and; 6) Other $(\mathrm{O})$. Likewise, the feeding guilds of avian were differentiated into different groups by Lambert [25] and Sheldon et al. [43], based on the trophic position, diet, movement, and behavioural patterns of the respective species. General information on the threatened resident avian species that are included in the meta-analysis of this study is listed out as shown in below Table 2 .

Other than avian count data, information related to habitat condition was extracted out from the selected 16 past studies. Wearn et al. [47] revealed that forest type, habitat degradation and management influenced shelter and food availabilities at a habitat directly. Henceforth, information related to the forest type, forest condition 


\section{Spatial Variation in the Abundances of Threatened Resident Avifauna across Sabah: A Meta-Analysis}

and management were extracted out from the given past studies, by referring to the interpretations employed in describing the condition of a sampling area or study site when the research was done there. Since the given past studies were conducted at different periods of time, thus scores were assigned as the representation of the habitat conditions of the given sampling areas or study sites at the respective times or years. The forest types that were identified in this research included 1) Island forest; 2) Mixed lowland dipterocarp forest (MLDF); 3) Wetland area, 4) Plantation forest, and; 4) Urban area. Moreover, forest condition was represented under four degradation levels, which ranged from 1) Undisturbed to; 2) Leastdisturbed; 3) Disturbed, and; 4) Heavily-disturbed. Last but not least, these sampling areas and study sites were determined to be managed either as a 1) Protected area, 2) Commercial forest; or; 3) State land, which reflected their respective functions in Sabah. Since there were differences in the sampling efforts (duration of the survey, and research size and type of area) and methods (e.g.: point-count, mist-netting, and recce walk surveys) between the given 16 past studies, henceforth there were large differences in the frequency of sighting between the different species and habitats, which could influence the result of this research if left unsolved. Because of that, by referring to Costantini et al. [12], relative abundance index (RAI) was estimated for each threatened resident avian species, to minimise the difference in frequency of sighting of each species at the different study sites and sampling areas.

Table 1: General description of the study sites and sampling areas included in the meta-analysis of this study

\begin{tabular}{|c|c|c|c|c|c|}
\hline Study Site & Sampling Area & Forest Type & Forest Condition & Management & References \\
\hline $\begin{array}{l}\text { Crocker Range } \\
\text { Park }\end{array}$ & Burned Area & MLDF & Disturbed & Protected Area & Sausan [39] \\
\hline Gaya Island & Primary Forest & Island & Undisturbed & Protected Area & Gilbert et al. [16] \\
\hline $\begin{array}{l}\text { Kawang Forest } \\
\text { Reserve }\end{array}$ & $\begin{array}{c}\text { Secondary- } \\
\text { regrowth Forest }\end{array}$ & MLDF & Least-disturbed & Protected Area & Salfinas [38] \\
\hline $\begin{array}{l}\text { Kota Kinabalu } \\
\text { Wetland Centre }\end{array}$ & Primary Forest & Wetland & Undisturbed & Protected Area & Mojiol et al. [31] \\
\hline Kudat District & $\begin{array}{c}\text { Coastal Area } \\
\text { Mangrove Forest }\end{array}$ & Wetland & Least-disturbed & Protected Area & Zulfa [50] \\
\hline $\begin{array}{l}\text { Mantanani Besar } \\
\text { Island }\end{array}$ & $\begin{array}{l}\text { Least-disturbed } \\
\text { Forest }\end{array}$ & Island & Least-disturbed & Protected Area & $\begin{array}{c}\text { Mojiol \& Yongoi } \\
{[32]}\end{array}$ \\
\hline $\begin{array}{l}\text { Maliau Basin } \\
\text { Studies Centre }\end{array}$ & Primary Forest & MLDF & Undisturbed & Protected Area & al. [40] \\
\hline Kota Kinabalu & Town Area & Urban & Disturbed & State Land & Hii [18] \\
\hline $\begin{array}{l}\text { Sabah Forest } \\
\text { Industries } \\
\text { (Sipitang) }\end{array}$ & $\begin{array}{l}\text { 2-YR Mangium } \\
\text { Plantation }\end{array}$ & Plantation & Heavily-disturbed & $\begin{array}{l}\text { Commercial } \\
\text { Forest }\end{array}$ & Kee [24] \\
\hline $\begin{array}{l}\text { Sungai Rawog } \\
\text { Conservation } \\
\text { Area }\end{array}$ & $\begin{array}{l}\text { Secondary- } \\
\text { regrowth Forest }\end{array}$ & MLDF & Least-disturbed & Protected Area & $\begin{array}{c}\text { Petol \& Rudolf } \\
\text { [33]; and Sompud } \\
\text { et al. [44] }\end{array}$ \\
\hline $\begin{array}{l}\text { Sabah Softwood } \\
\text { (Brumas) }\end{array}$ & $\begin{array}{l}\text { 2-YR Mangium } \\
\text { Plantation } \\
\text { 5-YR Mangium } \\
\text { Plantation } \\
\text { 7-YR Mangium } \\
\text { Plantation } \\
\text { Logged Forest }\end{array}$ & Plantation & Heavily-disturbed & $\begin{array}{l}\text { Commercial } \\
\text { Forest }\end{array}$ & Styring et al. [45] \\
\hline Tawau Hill Park & Primary Forest & MLDF & Undisturbed & Protected Area & Ten [46] \\
\hline $\begin{array}{l}\text { Universiti } \\
\text { Malaysia Sabah }\end{array}$ & $\begin{array}{c}\text { Secondary- } \\
\text { regrowth Forest }\end{array}$ & Urban & Disturbed & Stateland & Lim \& Mojiol [28] \\
\hline $\begin{array}{l}\text { Ulu-Segama- } \\
\text { Malua Forest } \\
\text { Reserve }\end{array}$ & $\begin{array}{l}\text { Logged Forest } \\
\text { Primary Forest }\end{array}$ & MLDF & $\begin{array}{c}\text { Disturbed } \\
\text { Undisturbed }\end{array}$ & $\begin{array}{l}\text { Commercial } \\
\text { Forest }\end{array}$ & $\begin{array}{c}\text { Edwards et al. } \\
\text { [14]; and Lambert } \\
{[25]}\end{array}$ \\
\hline
\end{tabular}

Note: $\mathrm{YR}=$ Year-old, and; MLDF = Mixed lowland dipterocarp forest. 
Spatial Variation in the Abundances of Threatened Resident Avifauna across Sabah: A Meta-Analysis

Table 2: A list of threatened resident bird species that are encountered at the 14 different study sites and 19 different sampling areas in Sabah, Malaysia

\begin{tabular}{|c|c|c|c|c|c|}
\hline Family & Local Name & Species & $\mathbf{I U C N}^{\mathrm{a}}$ & $\begin{array}{c}\text { Feeding } \\
\text { Guild }^{\mathrm{b}}\end{array}$ & Habitat $^{\mathrm{c}}$ \\
\hline Accipitridae & Wallace's Hawk-eagle & Nisaetus nanus & VU & $\mathrm{R}$ & FS \\
\hline \multirow[t]{5}{*}{ Bucerotidae } & Black Hornbill & Anthracoceros malayanus & VU & AFP & ETF \\
\hline & White-crowned Hornbill & Berenicornis comatus & EN & AFP & FS \\
\hline & Rhinoceros Hornbill & Buceros rhinoceros & VU & AFP & ETF \\
\hline & Helmeted Hornbill & Rhinoplax vigil & $\mathrm{CR}$ & AFP & ETF \\
\hline & Wreathed hornbill & Rhyticeros undulatus & VU & AFP & ETF \\
\hline \multirow[t]{2}{*}{ Ciconiidae } & Storm's Stork & Ciconia stormi & EN & MP & FS \\
\hline & Lesser Adjutant & Leptoptilos javanicus & VU & MP & OS \\
\hline \multirow[t]{2}{*}{ Columbidae } & Grey Imperial-pigeon & Ducula pickeringii & VU & $\mathrm{AF}$ & FS \\
\hline & Large Green-pigeon & Treron capellei & VU & $\mathrm{AF}$ & FS \\
\hline Cuculidae & Short-toed Coucal & Centropus rectunguis & VU & AFGI & FS \\
\hline Phasianidae & Chestnut-necklaced Partridge & Arborophila charltonii & VU & TIF & FS \\
\hline Chloropseidae & Greater Green Leafbird & Chloropsis sonnerati & EN & NIF & ETF \\
\hline Estrildidae & Java Sparrow & Lonchura oryzivora & VU & $\mathrm{TF}$ & OS \\
\hline Muscicapidae & Large-billed Blue-flycatcher & Cyornis caerulatus & VU & SI & FS \\
\hline Pellorneidae & Bornean Wren-babbler* & Ptilocichla leucogrammica & VU & TI & FS \\
\hline Pittidae & Blue-headed Pitta* & Hydrornis baudii & VU & TI & FS \\
\hline \multirow[t]{2}{*}{ Pycnonotidae } & Straw-headed Bulbul & Pycnonotus zeylanicus & $\mathrm{CR}$ & AFGIF & G \\
\hline & Hook-billed Bulbul & Setornis criniger & VU & AFGIF & ETF \\
\hline Picidae & Great Slaty Woodpecker & Mulleripicus pulverulentus & VU & BGI & ETF \\
\hline Psittacidae & Long-tailed Parakeet & Psittacula longicauda & VU & $\mathrm{AF}$ & ETF \\
\hline \multicolumn{6}{|c|}{$\begin{array}{l}\text { Note: } * \text { Avian species that is endemic to Sabah. } \\
\text { a IUCN = IUCN Red List Status, with extinction risk increases in an ascending order: 1) VU = Vulnerable; 2) EN = } \\
\text { Endangered, and; 3) Critically Endangered. } \\
{ }^{b} \text { Feeding guild is based on Lambert [25] and Sheldon et al. [43]: AF = Arboreal frugivore; AFGI = Arboreal foliage- } \\
\text { gleaning insectivore; AFGIF = Arboreal foliage-gleaning insectivore-frugivore; AFP = Arboreal frugivore-predator; BGI } \\
\text { = Bark gleaning insectivore; MP = Miscellaneous predator; NIF = Nocturnal insectivore-frugivore; R = Raptor; SI = } \\
\text { Sallying insectivore; TF = Terrestrial frugivore; TI, terrestrial insectivore, and; TIF, terrestrial insectivore-frugivore. } \\
{ }^{\mathrm{c}} \text { Habitat preference is based on Lambert [25] and Rotenburg [37]: ETF = Edge tolerant forest specialist; FS = Forest } \\
\text { specialist; G = Generalists, and; OS = Open country species. }\end{array}$} \\
\hline
\end{tabular}

RAI was estimated as the proportion of an avian species in a particular study site or sampling area, by using the following formula:

$$
R A I_{\tilde{U}}=\frac{n_{U I}}{w_{I}} \times 100 \%
$$

Where, $R A I_{i l}$ is the relative abundance index of species $i$ at area $I$, in percentage $(\%) ; n_{i I}$ is the number of sighting for species $i$ at area $I$, and; $N_{I}$ is the total number of bird sighting at area $I$. Then, $\log$ transformation was applied to increase the normality, heteroscedasticity, precision, and accuracy of the avian RAI dataset in meta-analysis. Then, the normality of the log-transformed RAI dataset was examined by using Shapiro-Wilk test, in which this dataset remained to be non-normally as well $(p<0.05)$. Therefore, non-parametric statistical analyses were used in this research, in which the difference in abundance of threatened resident avian species across the different habitats in Sabah was determined by using KruskalWallis one-way analysis of variance (ANOVA) test and followed by Mann-Whitney $U$ test as post-hoc analysis. After that, the strength and pattern of influence of the habitat condition towards spatial variation in abundance of the given bird species across the various habitats in Sabah were ascertained by using Spearman's Rank $(\rho)$ Correlation Test. Statistical analyses were run by using the statistical software IBM SPSS Statistics ver. 20.0.0 [20], at $95.0 \%$ confidence interval level $(p=0.05)$.

\section{RESULTS}

By referring to Table 2, a total of 21 threatened resident bird species were reported encountered across different 


\section{Spatial Variation in the Abundances of Threatened Resident Avifauna across Sabah: A Meta-Analysis}

habitats in Sabah. These bird species were comprised of 17 different families, where the hornbill (Bucerotidae) family was determined with the highest species number (5 or $23.8 \%$ ) in this research. Then, three families were identified with two recorded species each (Columbidae, Pycnonotidae, and Ciconiidae), whereas the remaining 12 species belonged to their respective families ( 1 or $4.76 \%$ each), including the vulnerable Bornean Wrenbabbler (Ptilocichla leucogrammica) and Blue-headed Pitta (Hydrornis baudii) that were endemic to Borneo. Moreover, 6 species (28.6\%) were only sighted at one specific habitat, whereas the remaining 15 species could be observed at two different habitats or more in Sabah at this moment. Among the given avian species, most of them were vulnerable species (16 or $76.2 \%$ ), arboreal frugivore predator species (AFP: 5 or $23.8 \%$ ), forest specialist species (FS: 10 or $47.6 \%$ ), and edge-tolerant forest specialist species (ETF: 7 or $33.3 \%$ ).

Findings of Kruskal-Wallis and Spearman's Rank Correlation tests indicated the fact that spatial variation in abundances of threatened resident avian species was statistically proven to be insignificant between different forest conditions $(p>0.05)$ in this research. Nonetheless, local abundances of the AF, AFGI, SI, AFP, BGI, NIF, TF, TI, ETF, FS and G species were generally higher at undisturbed habitats, whereas the AFGIF, MP, R, TIF, and OS species were found more abundant at disturbed and heavily-disturbed habitats. Furthermore, differences in abundance across different habitats were ascertained only for certain species and groups of species, based on their respective feeding guilds and habitat preferences $(p<0.05)$, as shown in Table 3 and Table 4 . Moreover, further information regarding the local abundances of the remaining species and groups of species of avifauna between different habitats in Sabah were compiled and displayed at the appendix section of this research paper (see Appendix A, Appendix B, and Appendix C).

Based on Table 2, only one TIF avian species was examined in this study, which was Chestnut-necklaced Partridge (Arborophila charltonii). The findings of this study revealed that there was a strong correlation $(\rho=-$ $0.625, p<0.01$ ) between forest conditions and the spatial variation in its abundances across the different habitats in Sabah. Due to that, the abundance of this species at the commercial forests $(R A I=0.20 \%)$ was significantly higher than at the local state lands and protected areas ( $R A I=$ Undetected at both sites, $H=8.087, p=0.018)$. On the contrary, the 5 hornbill species (AFP) were verified to be significantly more abundant at the mixed lowland dipterocarp forests (MLDFs: RAI=1.50\%) compared to the plantation areas ( $R A I=0.59 \%, H=12.057, p=0.017)$, especially Rhinoceros Hornbill (Buceros rhinoceros) as this species was significantly more abundant at MLDFs $(R A I=0.61 \%)$ than at the plantation areas $(R A I=0.16 \%$, $H=9.603, p=0.048$ ). Additionally, most of these species were ETF species, except the White-crowned Hornbill (Berenicornis comatus), which was identified as an FS species. Because of that, along with the Greater Green Leafbird (Chloropsis sonnerati), Long-tailed Parakeet (Psittacula longicauda), Hook-billed Bulbul (Setornis criniger), and Great Slaty Woodpecker (Mulleripicus pulverulentus), the local abundances of these species at MLDFs were confirmed to be very significantly higher $(R A I=2.67 \%)$ than those at plantation areas $(R A I=0.41$ $\% ; Z=-2.717, p=0.007)$, wetland forests $(R A I=0.72 \%$; $Z=-2.245, p=0.025)$, and island forests $(R A I=0.54 \%$; $Z=-2.089, p=0.037)$. Due to that, there was a significant difference in the abundance of these bird species across different forest types $(H=12.485, p=0.014)$. However, among the 4 non-hornbill ETF species, only the Greater Green Leafbird (NIF) was highly abundant at MLDFs, while the Great Slaty Woodpecker (BGI), Hook-billed Bulbul (AFGIF) and Long-tailed Parakeet (AF) were more abundant at island forests, plantation forests and urban areas respectively in this study. Moreover, spatial variation in abundances of these ETF species across the various habitats showed no correlations with the forest types and other parameters that were related to the local habitat conditions $(p>0.05)$. Therefore, spatial variation in abundance of the AFP and ETF species are generally not triggered by the habitat condition. Actually, Hookbilled Bulbul and Straw-headed Bulbul (Pycnonotus zeylanicus) are the two species that made up the group of arboreal foliage-gleaning insectivorous-frugivorous species (AFGIF) in this study. Then, they demonstrated spatial variation in abundances across different habitats, in terms of forest types $(H=13.135, p=0.011 ; \rho=-0.458$, $p<0.05)$, and also the management $(H=11.487, p=0.003$; $\rho=-0.64, p<0.01)$. Henceforth, abundances of these bird species at urban state lands $(R A I=1.64 \%)$ were verified to be significantly higher compared to those in wetland areas $(R A I=0.59 \%)$ that were located within protected areas $(R A I=0.18 \% ; Z=-2.538, p=0.011)$. Between these two species, Hook-billed Bulbul was significantly more abundant at state lands $(R A I=0.75 \%)$ than at both the protected area and commercial forest $(R A I=$ Undetected at both sites, $H=8.5, p=0.014$ ), although no factors were determined to correlate with the spatial variation in the abundance of the given AFGIF species across different habitats in Sabah as well. 
Spatial Variation in the Abundances of Threatened Resident Avifauna across Sabah: A Meta-Analysis

Table 3. Spatial variation in abundance of the threatened resident avian species across different habitats in Sabah.

\begin{tabular}{|c|c|c|c|c|c|c|c|}
\hline \multirow[b]{2}{*}{ Parameter } & \multicolumn{3}{|c|}{$\begin{array}{l}\text { Feeding } \\
\text { Guild }\end{array}$} & \multirow{2}{*}{$\begin{array}{c}\begin{array}{c}\text { Habitat } \\
\text { Preference }\end{array} \\
\text { ETF }\end{array}$} & \multicolumn{3}{|c|}{$\begin{array}{c}\text { Threatened Resident } \\
\text { Avian Species }\end{array}$} \\
\hline & AFGIF & AFP & TIF & & $\begin{array}{l}\text { Chestnut- } \\
\text { necklaced } \\
\text { Partridge }\end{array}$ & $\begin{array}{c}\text { Rhinoceros } \\
\text { Hornbill }\end{array}$ & $\begin{array}{l}\text { Hook-billed } \\
\text { Bulbul }\end{array}$ \\
\hline \multicolumn{8}{|l|}{ Forest Type } \\
\hline Island & - & - & - & $\begin{array}{c}0.536 \pm \\
0.341\end{array}$ & - & - & - \\
\hline MLDF & - & $\begin{array}{c}1.500 \pm \\
0.333\end{array}$ & $\begin{array}{c}0.155 \pm \\
0.077\end{array}$ & $\begin{array}{c}2.666 \pm \\
0.537\end{array}$ & $\begin{array}{c}0.155 \pm \\
0.077\end{array}$ & $\begin{array}{c}0.608 \pm \\
0.167\end{array}$ & - \\
\hline Plantation & - & $\begin{array}{c}0.161 \pm \\
0.127\end{array}$ & $\begin{array}{c}0.045 \pm \\
0.045\end{array}$ & $\begin{array}{c}0.412 \pm \\
0.172\end{array}$ & $\begin{array}{c}0.045 \pm \\
0.045\end{array}$ & $\begin{array}{c}0.155 \pm \\
0.077\end{array}$ & - \\
\hline Urban & $\begin{array}{c}1.639 \pm \\
0.147\end{array}$ & - & - & $\begin{array}{c}0.746 \pm \\
0.746\end{array}$ & - & - & $\begin{array}{c}0.746 \pm \\
0.746\end{array}$ \\
\hline Wetland & $\begin{array}{c}0.585 \pm \\
0.585 \\
\end{array}$ & - & - & $\begin{array}{c}0.719 \pm \\
0.186 \\
\end{array}$ & - & - & - \\
\hline Kruskal- $\quad H$ & 13.135 & 12.057 & 3.259 & 12.485 & 3.259 & 9.603 & 8.500 \\
\hline Wallis Test Sig. & 0.011* & 0.017* & 0.516 & 0.014* & 0.516 & 0.048* & 0.075 \\
\hline \multicolumn{8}{|l|}{ Management } \\
\hline $\begin{array}{l}\text { Commercial } \\
\text { Forest }\end{array}$ & - & $\begin{array}{c}0.875 \pm \\
0.432\end{array}$ & $\begin{array}{c}0.203 \pm \\
0.080\end{array}$ & $\begin{array}{l}1.272 \pm \\
0.439\end{array}$ & $\begin{array}{c}0.203 \pm \\
0.080\end{array}$ & $\begin{array}{c}0.399 \pm \\
0.199\end{array}$ & - \\
\hline Protected Area & $\begin{array}{c}0.175 \pm \\
0.175\end{array}$ & $\begin{array}{c}0.652 \pm \\
0.280\end{array}$ & (1) & $\begin{array}{c}1.730 \pm \\
0.550\end{array}$ & - & $\begin{array}{c}0.218 \pm \\
0.118\end{array}$ & - \\
\hline State Land & $\begin{array}{c}1.639 \pm \\
0.147 \\
\end{array}$ & - & - & $\begin{array}{c}0.746 \pm \\
0.746 \\
\end{array}$ & - & - & $\begin{array}{c}0.746 \pm \\
0.746 \\
\end{array}$ \\
\hline Kruskal- $\quad H$ & 11.487 & 2.288 & 8.087 & 1.142 & 8.087 & 2.101 & 8.500 \\
\hline Wallis Test Sig. & $0.003 * *$ & 0.319 & 0.018* & 0.565 & 0.018* & 0.350 & $0.014 *$ \\
\hline \multicolumn{8}{|c|}{$\begin{array}{l}\text { Note: } \mathrm{MLDF}=\text { Mixed lowland dipterocarp forest; AFGIF }=\text { Arboreal foliage-gleaning insectivore-frugivore; AFP }=\text { Arboreal } \\
\text { frugivore-predator; TIF, terrestrial insectivore-frugivore, and; ETF }=\text { Edge tolerant forest specialist. } \\
\text { Kruskal-Wallis Test: } H=\text { Statistics value, and; Sig. = Significance level (Kruskal-Wallis test: } *=\text { significant, } p<0.05 \text {, } \\
\text { and; } * *=\text { very significant, } p<0.01 ; 2 \text {-tailed). } \\
\text { This table only highlights the parameters with significant differences in mean RAI across different habitats, and then } \\
\text { standard error for the respective mean RAI value is shown in this table. }\end{array}$} \\
\hline \multicolumn{8}{|c|}{$\begin{array}{l}\text { Table 4. Significant Correlations between species traits and habitat conditions in influencing the spatial variation in } \\
\text { abundance of species and groups of species of threatened resident birds across the different habitats in Sabah }\end{array}$} \\
\hline & rameter & & & Forest Type & Forest C & ndition & Ianagement \\
\hline \multicolumn{8}{|l|}{ Feeding Guild } \\
\hline \multicolumn{4}{|c|}{$\begin{array}{l}\text { Arboreal Foliage-gleaning Insectivore- } \\
\text { Frugivore (AFGIF) }\end{array}$} & $0.522^{*}$ & \multicolumn{2}{|c|}{-} & $0.570^{* *}$ \\
\hline \multicolumn{4}{|c|}{ Terrestrial Insectivore-Frugivore (TIF) } & - & \multicolumn{2}{|c|}{-} & $-0.625^{* *}$ \\
\hline
\end{tabular}

\section{Threatened Resident Avian Species}

Chestnut-necklaced Partridge $\quad$ - $\quad$ - $\mathbf{- 0 . 6 2 5}^{\text {** }}$

Note: $\quad$ Spearman's Rank Correlation test (2-tailed): * = Significant $(\mathrm{p}<0.05)$, and; $* *=$ Very significant $(\mathrm{p}<0.01)$. 


\section{Spatial Variation in the Abundances of Threatened Resident Avifauna across Sabah: A Meta-Analysis}

\section{DISCUSSION}

The findings of this research highlighted that not every threatened resident avian species demonstrated distinct differences in abundance across the different habitats in Sabah. In this study, most of the MLDFs, island forests and wetland areas were actually undisturbed and leastdisturbed forests (see Table 1), and then 16 bird species $(76.2 \%)$ were found more abundant at one of the given forest habitats, except Wallace's Hawk-eagle (Nisaetus nanus), Lesser Adjutant (Leptoptilos javanicus), Strawheaded Bulbul, Long-tailed Parakeet, and Hook-billed Bulbul. This is because most of these species are forest and edge-tolerant forest specialist species that mainly inhabit primary and secondary MLDFs [22];[45]. Foods and shelters are highly available for them at undisturbed and least-disturbed MLDFs, and vice versa at disturbed habitats liked the urban and plantation forests [28];[47]. Due to that, only those who can adapt and survive at disturbed habitats (e.g.: OS G, and certain ETF species) can be found abundant at the local plantation and urban environments [27];[31]. Moreover, these 21 species only have small population sizes throughout the world at this moment [21], which can lead to the similar abundances for most of these bird species across the habitats varied in management, forest type and condition, except those which have adapted to only occupy at a distinct type of habitat environment in the state [25];[37].

Generally, different species and groups of species responded to a specific type, condition and management of habitat differently. Selective logging can create more forest gaps and subsequently promote the growth rate of understorey vegetation, thus creating more quantity and variety of foods and shelters for the wildlife community at a time [47]. Since the Chestnut-necklaced Partridge depends on terrestrial fruits and insects found at interior forests for survival [25];[37], therefore can result in the presence of this species at selective-logged commercial forests compared to the other forest habitats [27];[47]. In fact, Bakar [3] and Pegan et al. [32] also revealed that the MLDFs function as valuable habitats to this species, thus further supported the findings of this research.

Moving on, the two AFGIF species were reported sighted at urban forest habitats in Kota Kinabalu, Sabah [28];[31]. The straw-headed Bulbul is a generalist avian species that inhabits riparian secondary forests, scrubs and, plantation areas [11];[37,];[49], and nowadays it is mostly observed at local protected riparian forests [41]. However, it was reportedly sighted at the fragmented wetland and urban forests in Kota Kinabalu [18];[31], at the same time there was no significant difference in its abundances between these two habitats. This species is widely hunted illegally for pet-trading business, hence those which inhabits the urban area are highly prone to illegal hunting, which can lead to its small abundances as reported at the given fragmented urban and wetland forests [6];[19]. At the same time, Hookbilled Bulbul is a forest specialist species that inhabits the large lowland forests bordering freshwater bodies [9]. But, researchers failed to sight this species at MLDFs [45], and instead it was encountered at the large urban secondary-regrowth forest in Kota Kinabalu [28]. According to the findings of Ayat and Tata [2] and Rosli et al. [36], the AFGIF species showed preference towards interior forests with high plant diversity and good forest structure, due to the presence of high food availability at this habitat. Due to that, the presence of high food availability can result in the presence of these two AFGIF species at the given fragmented urban forests [29].

Moreover, the five hornbill species, especially the Rhinoceros Hornbill, were confirmed to be significantly more abundant at MLDFs than at the plantation areas in Sabah [14];[33];[39];[40];[45];[46]. The hornbill species (AFP) require large forests with the presences of sources of food and shelter that are favorable for their survival [23];[35], and then selective-logged MLDFs can provide higher abundance and more variety of food and shelter to them compared to other forest types in Sabah [2];[47]. Besides that, edge-tolerant hornbill species and one of the other four bird species that made up the ETP species in this study were also found significantly more abundant at MLDFs compared to the other forest types. Greater Green Leafbird mainly feeds on arthropods and fruits found at heavy woodlands and large forests for survival [48], unlike Hook-billed Bulbul, Long-tailed Parakeet and Great Slaty Woodpecker that can survive at other forest types [8];[9];[11]. Due to that, only the Greater Green Leafbird was found more abundant at the MLDFs, while the other three species were found more abundant at other forest types in the state.

Long story short, management and forest type is suitable to be applied in explaining the spatial variation in abundances, especially for certain species and groups of species of threatened resident avifauna, compared to forest conditions across Sabah. Type of human activity and vegetation community shape the species abundance and composition of avian that is presented at a habitat [37];[42], and then the long-term implementation of this particular activity can alter the suitability of this habitat for the local bird community [12];[14];[45]. Moreover, certain species can tolerate with habitat degradation to a certain degree and can adapat and survive at the given habitat, while those which have failed to survive at the disturbed environment will migrate to other habitats [4]. Due to that, the impact of forest condition onto spatial variation in abundances across habitats was determined to be insignificant for the given bird species, compared to management and forest type. Besides that, elevation 


\section{Spatial Variation in the Abundances of Threatened Resident Avifauna across Sabah: A Meta-Analysis}

was reported to have a direct impact on bird abundance, and indirect impact on the composition and structure of vegetation that determines the abundance of avian at a given habitat [13]. The lacking of information regarding to the habitat conditions of the given sampling areas and study sites has prevented this study from assessing the interrelated effects of these three parameters, plus the elevation, to the spatial variation in abundances of these species and groups of species across the different habitats in Sabah. Moreover, this research managed to cover only certain lowland habitats (e.g.: MLDF, urban, plantation, island, and wetland), where highland forests were excluded due to the lacking of past studies that provided the count data on the threatened resident avian species in Sabah. Additionally, the sampling techniques and designs employed in the given 16 past studies are different, plus specified for observing the avian species with low abundance. The variability in these factors can affect the quality of information produced by this study [1], in terms of its accuracy and precision. Because of that, findings of this study only focused on the spatial variation in abundances of certain species and groups of species of the threatened resident avian across Sabah, hence further research is required to include the other habitats and factors, and also other species and group of species in the meta-analysis.

\section{CONCLUSION}

The findings of this study have revealed that the habitat conditions only influence spatial variation in abundance of specific species and groups of species of threatened resident birds across Sabah. Certain species and groups of species have adapted to survive at a particular type of habitat environment, such as the AFGIF (Straw-headed Bulbul and Hook-billed Bulbul) species that are found more abundant at urban forest habitats, and also the TIF (Chestnut-necklaced Partridge), AFP (Bucerotidae) and ETF species that are found more abundant at selectivelogged MDLFs, compared to other forest habitats in the state. Then, the remaining species and groups of species exhibit no significant differences in abundances across different habitats, most likely due to their existing small population sizes throughout Sabah. A majority of these species are the forest and edge-tolerant forest specialist species that mainly inhabit the interior and edge regions of large forested areas, in which abundance and variety of food and shelter provided at the given habitats can be increased through selective-logging. Moreover, certain species can adapt and survive at the disturbed habitats, as long as their respective favourable sources of shelter and food are available in the given habitats. Because of that, most of these avian species are either found only at or more abundant at the selective-logged commercial forests. On the other hand, the remaining species can be observed more abundantly at the urban state lands and plantation forests, compared to other habitats in Sabah.

Long story short, availabilities of food and shelter dictate the presence/absence and abundance of a species or group of species of threatened resident avifauna at a particular habitat, as species and groups of species has its preferred habitat environment. The availabilities of these resources depend on the effect of human activity over the vegetation community presented at the habitat and subsequently affect the suitability of this habitat for these species here. On the contrary, habitat degradation may not necessarily affect the abundance and presence or absence of the given avian species, as some of them can tolerate habitat degradation to a certain degree and continue to survive at this habitat. Therefore, forest type and management are more suitable in explaining spatial variation in abundances of these avifauna species across Sabah, based on the findings of this study. Nonetheless, the lacking of relevant research materials has resulted in the exclusion of assessing the interrelated influences of these three parameters, and also the elevation and other forest types in addressing the given matter in this study. Therefore, further research onto these topics is required to provide a much comprehensive understanding of the effect of habitat conditions towards the spatial variation in abundances of threatened resident bird species across the different habitats in Sabah in the future.

\section{ACKNOWLEDGMENT}

We would like to give our sincere gratitude to the past researchers that provided the count data on threatened resident avian species presented in Sabah, which served as the fundamental database for us to run meta-analysis in this study. At the same time, we would like to give our thanks to fellow anonymous reviewers for spending their precious time reviewing and help to improve the quality of the information provided in this study.

\section{REFERENCES}

[1] Ancrenaz, M., 2013. Field Manual: Monitoring Large Terrestrial Mammals in Sabah. Sabah Forestry Department, Sandakan, Sabah.

[2] Ayat, A. and H.L. Tata, 2015. Diversity of Birds across Land Use and Habitat Gradients in Forests, Rubber Agroforests and Rubber Plantations of North Sumatra. Indonesian Journal of Forestry Research, 2(2), 103-120.

[3] Bakar, J., 2015. Bird Survey Report 2: Sugut Forest Reserve (11 $1^{\text {th }}$ to $15^{\text {th }}$ May 2015). Report 2. Sabah Forestry Department, Sabah, Malaysia.

[4] Batáry, P., S. Fronczek, C. Normann, C. Schreber and T. Tscharntke, 2014. How do edge effect and tree species diversity change bird diversity and avian nest survival in Germany's largest 
deciduous forest? Forest Ecology and Management, 319, 44-50.

[5] Bateman, P.W. and P.A. Fleming, 2017. Are negative effects of tourist activities on wildlife over-reported? A review of assessment methods and empirical results. Biological Conservation, 211, 10-19.

[6] Bergin, D., S.C.L. Chng, J.A. Eaton and C.R. Shepherd, 2018. The final straw? An overview of Straw-headed Bulbul Pycnonotus zeylanicus trade in Indonesia. Bird Conservation International, 28(1), 126-132.

[7] BirdLife International, 2017. Birds occur in all major habitat types, with forest being particularly important. (http://www.birdlife.org). Accessed on 26/05/2020.

[8] BirdLife International, 2016a. Mulleripicus pulverulentus. The IUCN Red List of Threatened Species 2016: e.T22681585A92911785.

[9] BirdLife International, 2016a. Setornis criniger. The IUCN Red List of Threatened Species 2016: e.T22713158A94362069.

[10] BirdLife International, 2018b. Psittacula longicauda. The IUCN Red List of Threatened Species 2018: e.T22685513A131365116.

[11] BirdLife International, 2018b. Pycnonotus zeylanicus. The IUCN Red List of Threatened Species 2018: e.T22712603A132470468.

[12] Costantini, D., D.P. Edwards and M.J.P. Simons, 2016. Life after logging in tropical forests of Borneo: A meta-analysis. Biological Conservation, 196, 182-188.

[13] Duclos, T.R., W.V. DeLuca and D.I. King, 2019. Direct and indirect effects of climate on bird abundance along elevation gradients in the Northern Appalachian Mountains. Diversity and Distributions, 25(11), 1670-1683.

[14] Edwards, D.P., T.H. Larsen, T.D.S. Docherty, F.A. Ansell, W.W. Hsu, M.A. Derhé, K.C. Hamer and D.S. Wilcove, 2011. Degraded lands worth protecting: The biological importance of Southeast Asia's repeatedly logged forests. Proceedings of the Royal Society B: Biological Sciences, 278(1702), 82-90.

[15] Ferrer, R.L., 1998. Graphical Methods for Detecting Bias in Meta-analysis. Family Medicine, 30(8), 579-83.

[16] Gilbert, E.A., J. Sompud, O.A. Igau, M. Lakim, R. Repin and A. Biun, 2018. An Update on the Bird Population in Gaya Island. Transactions on Science and Technology, 5(2), 171-176.

[17] Hamer, K.C., R.J. Newton, F.A. Edwards, S. Benedick, S.H. Bottrell and D.P. Edwards, 2015. Impacts of selective logging on insectivorous birds in Borneo: The importance of trophic position, body size and foraging height. Biological Conservation, 188, 82-88.

[18] Hii, S.M., 2006. Comparison in the Vegetation Structure and Avian Species Composition between Urban and Sub-urban Green Zone: A study on the Southeast and Southwest Region of Kota Kinabalu city. B.S. Thesis, Universiti Malaysia Sabah, Sabah.

[19] Holmes, D.A., 1997. Kalimantan bird report -2 . Kukila, 9, 141-169.

[20] IBM, 2011. IBM SPSS Statistics for Windows, Version 20.0. IBM Corporation, New York.

[21] IUCN Standards and Petitions Committee, 2019. Guidelines for Using the IUCN Red List Categories and Criteria. Version 14. Prepared by the Standards and Petitions Committee.

[22] Jain, A., J.G.H. Lee, N. Chao, C. Lees, R. Orenstein, B.C. Strange, S.C.L. Chng, W. Marthy, Y.C. Aik, Y.Y. Hadiprakarsa, and M. Rao (Eds), 2018. Helmeted Hornbill (Rhinoplax vigil): Status Review, Range-wide Conservation Strategy and Action Plan (2018-2027). IUCN Species Survival Commission Hornbill Specialist Group.

[23] Johns, A.D., 1982. Observations on nesting behaviour in the Rhinoceros hornbill, Buceros rhinoceros. Malayan Nature Journal 35: 173-177.

[24] Kee, S.L., 2016. The study of bird population in two-year-old Acacia mangium plantation, Sabah Forest Industries Sdn Bhd, Sabah. B.S. Thesis, Universiti Malaysia Sabah, Sabah.

[25] Lambert, F.R., 1992. The consequences of selective logging for Bornean lowland forest birds. Philosophical Transactions - Royal Society of London, B, 335(1275), 443-457.

[26] Larson, C.L., S.E. Reed, A.M. Merenlender and K.R. Crooks, 2019. A meta-analysis of recreation effects on vertebrate species richness and abundance. Conservation Science and Practice, 1(10), 1-9.

[27] Lerman, S.B., K.H. Nislow, D.J. Nowak, S. DeStefano, D.I. King and D.T. Jones-Farrand, 2014. Using urban forest assessment tools to model bird habitat potential. Landscape and Urban Planning, 122, 29-40.

[28] Lim, W.S. and A.R. Mojiol, 2019. A Preliminary Assessment on Avian Community in the Urban Forest of Universiti Malaysia Sabah. Transactions on Science and Technology, 6(3), 292-297.

[29] Miller, J.R., J.A. Wiens, N. Thompson Hobbs and D.M. Theobald, 2003. Effects of Human Settlement on Bird Communities in Lowland Riparian Areas of Colorado (USA). Ecological Applications, 13(4), 1041-1059.

[30] Mojiol, A.R. and W. Yongoi, 2019. Chapter 8: Rapid Observational Survey of Avifauna Carried Out at the Mantanani Besar Island, Sabah. In: 
Mohd Harun Abdullah, Ismail Ali, Zulherry Isnain, \& C.G. Joseph (Eds), Mantanani Island. Penerbit Universiti Malaysia Sabah, Kota Kinabalu, Sabah, Malaysia.

[31] Mojiol, A.R., A. Hassan, J. Maluda and S. Immit, 2008. Rapid assessment on the abundance of bird species utilising the Kota Kinabalu Wetland Centre mangroves. Journal of Tropical Biology and Conservation, 4(1), 99-107.

[32] Pegan, T.M., E.R. Gulson-Castillo, A. Biun, J.I. Byington, R.G. Moyle, F.T.Y. Yu, E.M. Wood, D. W. Winkler and F.H. Sheldon, 2018. An assessment of avifauna in a recovering lowland forest at Kinabalu National Park, Malaysian Borneo. Raffles Bulletin of Zoology, 66, 110-131.

[33] Petol, G.H. and V. Rudolf, 2019. Avifaunal survey of Sungai Rawog Conservation Area, Segaliud Lokan Forest Reserve. Proceedings of the Seminar on Sungai Rawog Conservation Area Scientific Expedition Segaliud Lokan Forest Reserve (FMU19B), Feb. 21, pp: 190-204.

[34] Phillipps, Q. \& K. Phillipps, 2014. Phillipps' Field Guide to the Birds of Borneo: Sabah, Sarawak, Brunei and Kalimantan. 3rd Edn., John Beaufoy Publishing Ltd. Oxford.

[35] Poonswad, P., C. Sukkasem, S. Phataramata, S. Hayeemuida, K. Plongmai, P. Chuailua, P. Thiensongrusame and N. Jirawatkavi, 2005. Comparison of cavity modification and community involvement as strategies for hornbill conservation in Thailand. Biological Conservation, 122(3), 385-393.

[36] Rosli, Z., M. Zakaria and M.N. Rajpar, 2018. Edge effects on foraging guilds of upperstory birds in an isolated tropical rainforest of Malaysia. Journal of Animal and Plant Sciences, 28(1), 307320.

[37] Rotenberg, J.A., 2007. Ecological Role of a Tree (Gmelina arborea) Plantation in Guatemala: An Assessment of an Alternative Land Use for Tropical Avian Conservation. The Auk, 124(1), 316-330.

[38] Salfinas, N., 2008. The study of bird species composition in forest plantation and domestic forest areas at Kinarut, Papar, Sabah. B.S. Thesis, Universiti Malaysia Sabah, Sabah.

[39] Sausan, R., 2011. Comparison in the bird diversity between two different altitudinal zones in Crocker Range Park, Keningau, Sabah. B.S. Thesis, Universiti Malaysia Sabah, Sabah.

[40] Seekar, R., N.T.P. Le and R.D. Harrison, 2010. Vertebrate assemblage at a fruiting fig (Ficus caulocarpa) in Maliau Basin, Malaysia. Tropical Conservation Science, 3(2), 218-227.

[41] Sheldon, F.H., H.C. Lim, J. Nais, J., M. Lakim, A. Tuuga, P. Malim, J. Majuakim, A. Lo, M.
Schilthuizen, P.A. Hosner and R.G. Moyle, 2009. Observations on the ecology, distribution and biogeography of forest birds in Sabah, Malaysia. Raffles Bulletin of Zoology, 57(2), 577-586.

[42] Sheldon, F.H., A. Styring and P.A. Hosner, 2010. Bird species richness in a Bornean exotic tree plantation: A long-term perspective. Biological Conservation, 143(2), 399-407.

[43] Sheldon, F.H., R.G. Moyle and J. Kennard, 2001. Ornithology of Sabah: history, gazetteer, annotated checklist, and bibliography. Ornithological Monographs 52, 1-285.

[44] Sompud, J., A. Ambrose, E.A. Gilbert, A.J. Embug, S. Gasinin, N. Muroi, and K. Kos, 2019. Wildlife survey along the Rawog River Conservation Area, Segaliud Lokan Forest Reserve. Proceedings of the Seminar on Sungai Rawog Conservation Area Scientific Expedition Segaliud Lokan Forest Reserve (FMU19B), Feb. 21, pp: 167-177.

[45] Styring, A.R., R. Ragai, J. Unggang, R. Stuebing, P.A. Hosner and F.H. Sheldon, 2011. Bird community assembly in Bornean industrial tree plantations: Effects of forest age and structure. Forest Ecology and Management, 261(3), 531544.

[46] Ten, W.L. 2018. Distribution of bird species and their role as ecotourism attraction in Tawau Hill Park, Sabah. B.S. Thesis, Universiti Malaysia Sabah, Sabah.

[47] Wearn, O.R., J.M. Rowcliffe, C. Carbone, M. Pfeifer, H. Bernard and R.M. Ewers, 2017. Mammalian species abundance across a gradient of tropical land-use intensity: A hierarchical multi-species modelling approach. Biological Conservation, 212, 162-171.

[48] Wells, D., 2016. Greater Green Leafbird (Chloropsis sonnerati). In: del Hoyo, J., Elliott, A., J. Sargatal, D.A. Christie and E. de Juana (Eds), Handbook of the Birds of the World Alive. Lynx Edicions, Barcelona.

[49] Yong, D.L., K.S. Lim, K.C. Lim, T., Tan, S. Teo and H.C. Ho, 2018. Significance of the globally threatened Straw-headed Bulbul Pycnonotus zeylanicus populations in Singapore: A last straw for the species? Bird Conservation International, 28(1), 133-144.

[50] Zulfa. 2008. Preliminary study on avian species at the suburb regions of mangrove forests, Sikuati, Kudat. B.S. Thesis, Universiti Malaysia Sabah, Sabah. 
Spatial Variation in the Abundances of Threatened Resident Avifauna across Sabah: A Meta-Analysis

Appendix A: Relative abundance indices (RAI and standard error values) of the species and groups of species of threatened resident avifauna across the habitats varied in forest types in Sabah

\begin{tabular}{|c|c|c|c|c|c|c|}
\hline & \multirow{2}{*}{ Parameter } & \multicolumn{5}{|c|}{ Forest Type } \\
\hline & & Island & MLDF & Plantation & Urban & Wetland \\
\hline \multirow{12}{*}{ 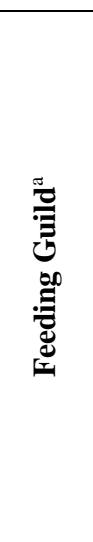 } & $\mathrm{AF}$ & $0.439 \pm 0.439$ & $0.226 \pm 0.208$ & $0.045 \pm 0.045$ & - & - \\
\hline & AFGI & - & $0.247 \pm 0.153$ & - & - & - \\
\hline & AFGIF & - & - & - & $1.639 \pm 0.147$ & $0.585 \pm 0.585$ \\
\hline & AFP & - & $1.500 \pm 0.333$ & $0.161 \pm 0.127$ & - & - \\
\hline & BGI & $0.536 \pm 0.341$ & $0.100 \pm 0.050$ & - & - & $0.524 \pm 0.314$ \\
\hline & MP & - & $0.102 \pm 0.102$ & $0.292 \pm 0.292$ & - & $0.195 \pm 0.195$ \\
\hline & NIF & - & $1.099 \pm 0.521$ & $0.206 \pm 0.100$ & - & $0.195 \pm 0.195$ \\
\hline & $\mathrm{R}$ & - & $0.008 \pm 0.005$ & - & $0.498 \pm 0.498$ & - \\
\hline & SI & - & $0.264 \pm 0.139$ & $0.073 \pm 0.073$ & - & - \\
\hline & $\mathrm{TF}$ & $0.219 \pm 0.219$ & - & $0.146 \pm 0.146$ & - & $0.162 \pm 0.162$ \\
\hline & TI & - & $0.282 \pm 0.195$ & - & - & - \\
\hline & $\mathrm{TIF}$ & - & $0.155 \pm 0.077$ & $0.045 \pm 0.045$ & - & - \\
\hline \multirow{4}{*}{ 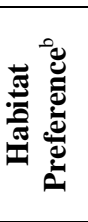 } & ETF & $0.536 \pm 0.341$ & $2.666 \pm 0.537$ & $0.412 \pm 0.172$ & $0.746 \pm 0.746$ & $0.719 \pm 0.186$ \\
\hline & FS & $0.439 \pm 0.439$ & $1.319 \pm 0.44$ & $0.118 \pm 0.072$ & $0.498 \pm 0.498$ & - \\
\hline & G & - & - & - & $0.893 \pm 0.893$ & $0.585 \pm 0.585$ \\
\hline & OS & $0.219 \pm 0.219$ & - & $0.439 \pm 0.439$ & - & $0.357 \pm 0.181$ \\
\hline \multirow{21}{*}{ 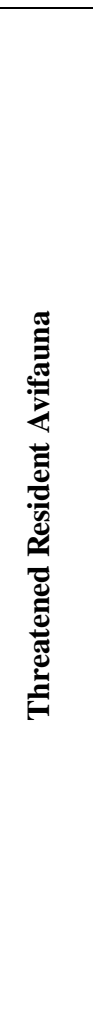 } & Black Hornbill & - & $0.398 \pm 0.211$ & $0.134 \pm 0.134$ & - & - \\
\hline & Blue-headed Pitta & - & $0.164 \pm 0.109$ & - & - & - \\
\hline & Bornean Wren-babbler & - & $0.118 \pm 0.090$ & - & - & - \\
\hline & Chestnut-necklaced Partridge & - & $0.155 \pm 0.077$ & $0.045 \pm 0.045$ & - & - \\
\hline & Great Slaty Woodpecker & $0.536 \pm 0.341$ & $0.100 \pm 0.050$ & - & - & $0.524 \pm 0.314$ \\
\hline & Greater Green Leafbird & - & $1.099 \pm 0.521$ & $0.206 \pm 0.100$ & - & $0.195 \pm 0.195$ \\
\hline & Grey Imperial-pigeon & $0.439 \pm 0.439$ & - & - & - & - \\
\hline & Helmeted Hornbill & - & $0.166 \pm 0.095$ & - & - & - \\
\hline & Hook-billed Bulbul & - & - & - & $0.746 \pm 0.746$ & - \\
\hline & Java Sparrow & $0.219 \pm 0.219$ & - & $0.146 \pm 0.146$ & - & $0.162 \pm 0.162$ \\
\hline & Large Green-pigeon & - & $0.222 \pm 0.209$ & - & - & - \\
\hline & Large-billed Blue-flycatcher & - & $0.264 \pm 0.139$ & $0.073 \pm 0.073$ & - & - \\
\hline & Lesser Adjutant & - & - & $0.292 \pm 0.292$ & - & $0.195 \pm 0.195$ \\
\hline & Long-tailed Parakeet & - & $0.004 \pm 0.004$ & $0.045 \pm 0.045$ & - & - \\
\hline & Rhinoceros Hornbill & - & $0.608 \pm 0.167$ & $0.028 \pm 0.028$ & - & - \\
\hline & Short-toead Coucal & - & $0.247 \pm 0.153$ & - & - & - \\
\hline & Storm's Stork & - & $0.102 \pm 0.102$ & - & - & - \\
\hline & Straw-headed Bulbul & - & - & - & $0.893 \pm 0.893$ & $0.585 \pm 0.585$ \\
\hline & Wallace's Hawk-eagle & - & $0.008 \pm 0.005$ & - & $0.498 \pm 0.498$ & - \\
\hline & White-crowned Hornbill & - & $0.037 \pm 0.028$ & - & - & - \\
\hline & Wreathed hornbill & - & $0.291 \pm 0.203$ & - & - & - \\
\hline
\end{tabular}

Note: $\quad \mathrm{RAI}=$ Relative abundance index (\%).

${ }^{\text {a }}$ Feeding guild is based on Lambert [25] and Sheldon et al. [43]: AF = Arboreal frugivore; AFGI = Arboreal foliagegleaning insectivore; AFGIF = Arboreal foliage-gleaning insectivore-frugivore; AFP = Arboreal frugivore-predator; BGI $=$ Bark gleaning insectivore; $\mathrm{MP}=$ Miscellaneous predator; NIF $=$ Nocturnal insectivore-frugivore; $\mathrm{R}=\mathrm{Raptor} ; \mathrm{SI}=$ Sallying insectivore; TF = Terrestrial frugivore; TI, terrestrial insectivore, and; TIF, terrestrial insectivore-frugivore.

${ }^{\mathrm{b}}$ Habitat preference is based on Lambert [25] and Rotenburg [37]: ETF = Edge tolerant forest specialist; FS = Forest specialist; $\mathrm{G}=$ Generalists, and; OS = Open country species. 
Spatial Variation in the Abundances of Threatened Resident Avifauna across Sabah: A Meta-Analysis

Appendix B: Relative abundance indices (RAI and standard error values) of the species and groups of species of threatened resident avifauna across the habitats varied in forest conditions in Sabah

\begin{tabular}{|c|c|c|c|c|c|}
\hline & \multirow{2}{*}{ Parameter } & \multicolumn{4}{|c|}{ Forest Condition } \\
\hline & & Undisturbed & Least-disturbed & Disturbed & Heavily-disturbed \\
\hline \multirow{12}{*}{ 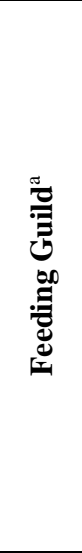 } & $\mathrm{AF}$ & $0.362 \pm 0.331$ & $0.175 \pm 0.175$ & - & $0.059 \pm 0.059$ \\
\hline & AFGI & $0.336 \pm 0.239$ & - & $0.050 \pm 0.050$ & - \\
\hline & AFGIF & $0.351 \pm 0.351$ & - & $0.546 \pm 0.348$ & - \\
\hline & AFP & $1.385 \pm 0.596$ & $0.328 \pm 0.328$ & $0.573 \pm 0.309$ & $0.215 \pm 0.163$ \\
\hline & BGI & $0.146 \pm 0.064$ & $0.490 \pm 0.222$ & $0.044 \pm 0.044$ & - \\
\hline & MP & $0.117 \pm 0.117$ & $0.164 \pm 0.164$ & - & $0.390 \pm 0.390$ \\
\hline & NIF & $0.922 \pm 0.775$ & $0.670 \pm 0.492$ & $0.235 \pm 0.222$ & $0.274 \pm 0.102$ \\
\hline & $\mathrm{R}$ & $0.007 \pm 0.007$ & - & $0.171 \pm 0.165$ & - \\
\hline & SI & $0.270 \pm 0.186$ & - & $0.127 \pm 0.127$ & $0.097 \pm 0.097$ \\
\hline & $\mathrm{TF}$ & - & $0.185 \pm 0.113$ & - & $0.195 \pm 0.195$ \\
\hline & $\mathrm{TI}$ & $0.293 \pm 0.293$ & - & $0.133 \pm 0.133$ & - \\
\hline & TIF & $0.065 \pm 0.065$ & - & $0.182 \pm 0.091$ & - \\
\hline \multirow{4}{*}{ 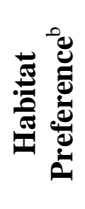 } & ETF & $2.414 \pm 1.060$ & $1.488 \pm 0.423$ & $1.090 \pm 0.384$ & $0.549 \pm 0.147$ \\
\hline & FS & $1.372 \pm 0.658$ & $0.339 \pm 0.208$ & $0.674 \pm 0.381$ & $0.097 \pm 0.097$ \\
\hline & G & $0.351 \pm 0.351$ & - & $0.298 \pm 0.298$ & - \\
\hline & OS & $0.117 \pm 0.117$ & $0.185 \pm 0.113$ & - & $0.585 \pm 0.585$ \\
\hline \multirow{21}{*}{ 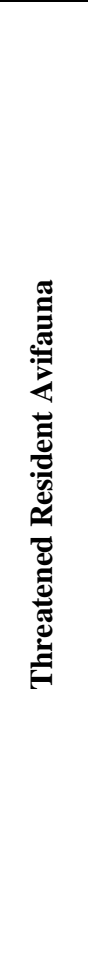 } & Black Hornbill & $0.427 \pm 0.326$ & $0.164 \pm 0.164$ & $0.039 \pm 0.039$ & $0.178 \pm 0.178$ \\
\hline & Blue-headed Pitta & $0.150 \pm 0.150$ & - & $0.094 \pm 0.094$ & - \\
\hline & Bornean Wren-babbler & $0.143 \pm 0.143$ & - & $0.039 \pm 0.039$ & - \\
\hline & Chestnut-necklaced Partridge & $0.065 \pm 0.065$ & - & $0.182 \pm 0.091$ & - \\
\hline & Great Slaty Woodpecker & $0.146 \pm 0.064$ & $0.490 \pm 0.222$ & - & $0.044 \pm 0.044$ \\
\hline & Greater Green Leafbird & $0.922 \pm 0.775$ & $0.670 \pm 0.492$ & $0.235 \pm 0.222$ & $0.274 \pm 0.102$ \\
\hline & Grey Imperial-pigeon & - & $0.175 \pm 0.175$ & - & - \\
\hline & Helmeted Hornbill & $0.198 \pm 0.151$ & - & $0.057 \pm 0.043$ & - \\
\hline & Hook-billed Bulbul & - & - & $0.249 \pm 0.249$ & - \\
\hline & Java Sparrow & - & $0.185 \pm 0.113$ & - & $0.195 \pm 0.195$ \\
\hline & Large Green-pigeon & $0.356 \pm 0.332$ & - & - & - \\
\hline & Large-billed Blue-flycatcher & $0.270 \pm 0.186$ & - & $0.127 \pm 0.127$ & $0.097 \pm 0.097$ \\
\hline & Lesser Adjutant & $0.117 \pm 0.117$ & - & - & $0.390 \pm 0.390$ \\
\hline & Long-tailed Parakeet & $0.007 \pm 0.007$ & - & - & $0.059 \pm 0.059$ \\
\hline & Rhinoceros Hornbill & $0.355 \pm 0.265$ & $0.164 \pm 0.164$ & $0.378 \pm 0.178$ & $0.037 \pm 0.037$ \\
\hline & Short-toead Coucal & $0.336 \pm 0.239$ & - & $0.050 \pm 0.050$ & - \\
\hline & Storm's Stork & - & $0.164 \pm 0.164$ & - & - \\
\hline & Straw-headed Bulbul & $0.351 \pm 0.351$ & - & $0.298 \pm 0.298$ & - \\
\hline & Wallace's Hawk-eagle & $0.007 \pm 0.007$ & - & $0.171 \pm 0.165$ & - \\
\hline & White-crowned Hornbill & $0.046 \pm 0.046$ & - & $0.011 \pm 0.011$ & - \\
\hline & Wreathed hornbill & $0.359 \pm 0.320$ & - & $0.088 \pm 0.088$ & - \\
\hline
\end{tabular}

Note: $\quad$ RAI $=$ Relative abundance index $(\%)$.

${ }^{a}$ Feeding guild is based on Lambert [25] and Sheldon et al. [43]: AF = Arboreal frugivore; AFGI = Arboreal foliagegleaning insectivore; AFGIF = Arboreal foliage-gleaning insectivore-frugivore; $\mathrm{AFP}=$ Arboreal frugivore-predator; $\mathrm{BGI}$ = Bark gleaning insectivore; $\mathrm{MP}=$ Miscellaneous predator; NIF = Nocturnal insectivore-frugivore; $\mathrm{R}=\mathrm{Raptor} ; \mathrm{SI}=$ Sallying insectivore; TF = Terrestrial frugivore; TI, terrestrial insectivore, and; TIF, terrestrial insectivore-frugivore.

${ }^{\mathrm{b}}$ Habitat preference is based on Lambert [25] and Rotenburg [37]: ETF = Edge tolerant forest specialist; FS = Forest specialist; $\mathrm{G}=$ Generalists, and; OS = Open country species. 
Spatial Variation in the Abundances of Threatened Resident Avifauna across Sabah: A Meta-Analysis

Appendix C: Relative abundance indices (RAI and standard error values) of the species and groups of species of threatened resident avifauna across the habitats varied in management in Sabah

\begin{tabular}{|c|c|c|c|c|}
\hline & \multirow{2}{*}{ Parameter } & \multicolumn{3}{|c|}{ Management } \\
\hline & & Commercial Forest & Protected Area & State Land \\
\hline \multirow{12}{*}{ 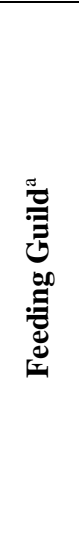 } & $\mathrm{AF}$ & - & $0.044 \pm 0.029$ & $0.256 \pm 0.181$ \\
\hline & AFGI & $0.108 \pm 0.072$ & $0.122 \pm 0.122$ & - \\
\hline & AFGIF & - & $0.175 \pm 0.175$ & $1.639 \pm 0.147$ \\
\hline & AFP & $0.875 \pm 0.431$ & $0.652 \pm 0.280$ & - \\
\hline & BGI & $0.084 \pm 0.055$ & $0.286 \pm 0.127$ & - \\
\hline & MP & $0.167 \pm 0.167$ & $0.140 \pm 0.095$ & - \\
\hline & NIF & $0.324 \pm 0.181$ & $0.793 \pm 0.436$ & - \\
\hline & $\mathrm{R}$ & $0.009 \pm 0.006$ & - & $0.498 \pm 0.498$ \\
\hline & SI & $0.286 \pm 0.153$ & $0.041 \pm 0.041$ & - \\
\hline & $\mathrm{TF}$ & $0.084 \pm 0.084$ & $0.092 \pm 0.062$ & - \\
\hline & TI & $0.323 \pm 0.221$ & - & - \\
\hline & TIF & $0.203 \pm 0.080$ & - & - \\
\hline \multirow{4}{*}{ 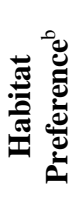 } & ETF & $1.272 \pm 0.439$ & $1.730 \pm 0.550$ & $0.746 \pm 0.746$ \\
\hline & FS & $0.984 \pm 0.534$ & $0.501 \pm 0.222$ & $0.498 \pm 0.498$ \\
\hline & $\mathrm{G}$ & - & $0.175 \pm 0.175$ & $0.893 \pm 0.893$ \\
\hline & OS & $0.251 \pm 0.251$ & $0.151 \pm 0.078$ & - \\
\hline \multirow{21}{*}{ 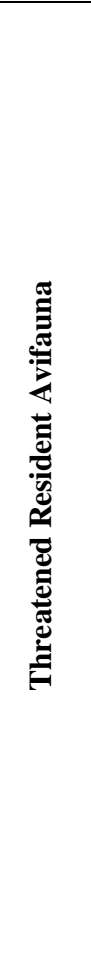 } & Black Hornbill & $0.175 \pm 0.089$ & $0.250 \pm 0.179$ & - \\
\hline & Blue-headed Pitta & $0.187 \pm 0.123$ & - & - \\
\hline & Bornean Wren-babbler & $0.135 \pm 0.102$ & - & - \\
\hline & Chestnut-necklaced Partridge & $0.203 \pm 0.080$ & - & - \\
\hline & Great Slaty Woodpecker & $0.084 \pm 0.055$ & $0.286 \pm 0.127$ & - \\
\hline & Greater Green Leafbird & $0.324 \pm 0.181$ & $0.793 \pm 0.436$ & - \\
\hline & Grey Imperial-pigeon & - & $0.088 \pm 0.088$ & - \\
\hline & Helmeted Hornbill & $0.160 \pm 0.110$ & $0.021 \pm 0.021$ & - \\
\hline & Hook-billed Bulbul & - & - & $0.746 \pm 0.746$ \\
\hline & Java Sparrow & $0.084 \pm 0.084$ & $0.092 \pm 0.062$ & - \\
\hline & Large Green-pigeon & $0.014 \pm 0.014$ & $0.168 \pm 0.168$ & - \\
\hline & Large-billed Blue-flycatcher & $0.286 \pm 0.153$ & $0.041 \pm 0.041$ & - \\
\hline & Lesser Adjutant & $0.167 \pm 0.167$ & $0.058 \pm 0.058$ & - \\
\hline & Long-tailed Parakeet & $0.030 \pm 0.025$ & - & - \\
\hline & Rhinoceros Hornbill & $0.399 \pm 0.199$ & $0.218 \pm 0.118$ & - \\
\hline & Short-toead Coucal & $0.108 \pm 0.072$ & $0.122 \pm 0.122$ & - \\
\hline & Storm's Stork & - & $0.082 \pm 0.082$ & - \\
\hline & Straw-headed Bulbul & - & $0.175 \pm 0.175$ & $0.893 \pm 0.893$ \\
\hline & Wallace's Hawk-eagle & $0.009 \pm 0.006$ & - & $0.498 \pm 0.498$ \\
\hline & White-crowned Hornbill & $0.042 \pm 0.032$ & - & - \\
\hline & Wreathed hornbill & $0.099 \pm 0.075$ & $0.163 \pm 0.163$ & - \\
\hline
\end{tabular}

Note: $\quad$ RAI $=$ Relative abundance index $(\%)$.

${ }^{a}$ Feeding guild is based on Lambert [25] and Sheldon et al. [43]: AF = Arboreal frugivore; AFGI = Arboreal foliagegleaning insectivore; AFGIF = Arboreal foliage-gleaning insectivore-frugivore; $\mathrm{AFP}=$ Arboreal frugivore-predator; $\mathrm{BGI}$ = Bark gleaning insectivore; $\mathrm{MP}=$ Miscellaneous predator; NIF = Nocturnal insectivore-frugivore; $\mathrm{R}=\mathrm{Raptor} ; \mathrm{SI}=$ Sallying insectivore; TF = Terrestrial frugivore; TI, terrestrial insectivore, and; TIF, terrestrial insectivore-frugivore.

${ }^{\mathrm{b}}$ Habitat preference is based on Lambert [25] and Rotenburg [37]: ETF = Edge tolerant forest specialist; FS = Forest specialist; $\mathrm{G}=$ Generalists, and; OS = Open country species. 